\title{
STRATEGI PEMBERDAYAAN EKONOMI SANTRI DAN MASYARAKAT DI LINGKUNGAN PONDOK PESANTREN WIRAUSAHA LANTABUR KOTA CIREBON
}

\author{
Ilham Bustomi dan Khotibul Umam \\ Fakultas Syari'ah dan Ekonomi Islam \\ Institut Agama Islam Negeri Syekh Nurjati Cirebon \\ email: ilham_aburaihan@yahoo.com dan khotibulumam454@yahoo.co.id
}

\begin{abstract}
More than just an interaction between Islamic religion leader and students, even boarding school also interacts with the surrounding communities. These interactions ultimately undergoes the transformation of meaning and role, direct to the changes, development and empowerment students, which is manifested in the form of a multi-faceted, including into the awareness of the issues facing particular economic problems. This is where potential boarding schools by performing its role as the Community institutions to increase the initiative and creative of the community as the main source of development and that emphasizes the material and spiritual wellbeing of the community as the goal of the development process. Of research results, empowerment programmes were successfully conducted by boarding schools Lantabur the entrepreneurial city of Cirebon, however there is still implementation in factor endowments and a barrier. Factor endowments, among others; the presence of equipment that had enough support. The presence of the tutelage of caretaker cottage, and the presence of a pretty good networking of Jama'ah Greeting Tour. The factor a barrier is still weak spirit of entrepreneurship among the public.
\end{abstract}

Keywords: Interactions, Development Process, Entrepreneurship, and Boarding Schools.

\begin{abstract}
Abstrak
Lebih dari sekedar interaksi antara kyai dan santri, bahkan pesantren juga berinteraksi dengan masyarakat sekitar. Interaksi tersebut pada akhirnya mengalami transformasi makna dan peran, yakni mengarahkan kepada perubahan, pengembangan dan keberdayaan santri, yang diwujudkan dalam bentuk yang beraneka ragam, termasuk ke dalam kepedulian terhadap masalah yang dihadapi khususnya masalah ekonomi. Disinilah potensi pesantren dengan melakukan perannya sebagai lembaga kemasyarakatan untuk meningkatkan inisiatif dan kreatif dari masyarakat sebagai sumber utama pembangunan dan yang menekankan kesejahteraan material dan spiritual masyarakat sebagai tujuan dari proses pembangunan. Dari hasil penelitian, program-program pemberdayaan telah berhasil dilakukan oleh pihak Pondok Pesantren Wirausaha Lantabur Kota Cirebon, akan tetapi dalam pelaksanaanya masih terdapat faktor pendukung dan penghambat. Faktor pendukung antara lain; adanya peralatan yang sudah cukup mendukung. Adanya pengawasan dari pengurus pondok, dan adanya jaringan yang cukup bagus dari Jama'ah Salam Tour. Faktor penghambatnya adalah masih lemahnya semangat berwirausaha di kalangan masyarakat.
\end{abstract}

Kata Kunci: Interaksi, Proses Pembangunan, Wira Usaha, dan Pondok Pesantren. 


\section{PENDAHULUAN}

Pondok pesantren dengan berbagai harapan dan predikat yang diletakkan padanya, sesungguhnya berujung pada tiga fungsi utama, yaitu pertama, sebagai pusat pengkaderan pemikir-pemikir agama (center of excellence). Kedua, sebagai lembaga yang mencetak sumber daya manusia (human resource). Dan ketiga, sebagai lembaga yang mempunyai kekuatan melakukan pemberdayaan pada masyarakat (agent of development). ${ }^{1}$

Corak pendidikan Islam tertua yang telah memberikan ragam istimewa dalam keberagaman masyarakat muslim Indonesia. Corak dan ragam yang dimaksud di sini antara lain karena ia tidak hanya menjadi tempat belajar, tetapi juga menjadi pola hubungan interaksi kyai dan santri terjalin amat erat dan nilai-nilai keagamaan inilah yang menjadi dasar pertimbangan penyelenggaran pondok pesantren. Pondok pesantren sebagai salah satu basis bantuan sosial dan pusat pendidikan keagamaan yang dapat memberikan motivasi bagi masyarakat yang berada di sekitarnya. $^{2}$

Pondok pesantren merupakan lembaga pendidikan untuk mencetak manusia yang religius dan mandiri. ${ }^{3}$ Para santri dididik dan dibina dalam meningkatkan jiwa kewirausahaan. Dengan demikian, pesantren dapat menjadi pusat kelembagaan ekonomi,

\footnotetext{
${ }^{1}$ Suhartini, "Problem Kelembagaan Pengembangan Ekonomi Pesantren", dalam Pustaka Pesantren (ed.), Manajemen Pesantren (Yogyakarta: LKIS, 2009), 233.

${ }^{2}$ Ebah Suaiybah, "Pemberdayaan Ekonomi Santri Melalui Penanaman Jamur Tiram (Studi Kasus di Pondok Pesantren Al-Ma'muroh Desa Susukan Kecamatan Cipicung Kabupaten Kuningan Jawa Barat)", Skripsi (Yogyakarta: UIN Sunan Kalijaga, 2009), 4.

${ }^{3}$ Hasbi Indra, Pesantren dan Transformasi Sosial Study atas Pemikiran KH. Abdullah Syafe'i dalam Bidang Pendidikan Islam (Jakarta: Permadani, 2005), 77.
}

bagi warganya di dalam maupun di luar pesantren. ${ }^{4}$

Fungsi lainnya yaitu sebagai instrumen untuk tetap melestarikan ajaranajaran Islam di bumi Nusantara, karena pondok pesantren mempunyai pengaruh yang kuat dalam membentuk dan memelihara kehidupan sosial, kultural, politik, keagamaan, dan sebagainya. ${ }^{5}$

Di sisi lain, kemiskinan yang diderita oleh masyarakat Indonesia yang mayoritas muslim tidak hanya masalah kecerdasan, tetapi juga masalah keahlian hidup, karena keahlian membuat masyarakat atau orang menjadi survive dalam menjalani hidup dan mencapai apa yang mereka inginkan, begitu juga sebaliknya. Tanpa keahlian hidup mereka tidak akan mendapat peluang untuk memenangkan kompetisi hidup yang semakin keras. ${ }^{6}$ Dengan demikian dapat dipahami bahwa kemiskinan lebih cenderung diakibatkan karena individu atau masyarakat tidak mampu memberdayakan potensi yang dimiliki secara maksimal, pada hakikatnya kemiskinan tidak menimbulkan keresahan, tetapi ia akan meresahkan apabila secara kontras berhadapan langsung dengan kemewahan. Para ilmuan sosial menyebut situasi tersebut sebagai deprivation. Deprivai selalu menimbulkan keresahan sosial (social unrest) yang pada gilirannya akan menimbulkan disintegrasi sosial. $^{7}$

Oleh karena itu, pondok pesantren Wirausaha Lantabur berusaha membekali santri dengan keterampilan wirausaha. Hal ini sesuai dengan misinya yaitu menyelenggarakan pendidikan pesantren

${ }^{4}$ Disarikan dari Ahmad Faozan, "Pondok Pesantren dan Pemberdayaan Ekonomi", Jurnal Ibda', Vol. 4, No. 1 (Juni, 2006): 1-12.

${ }^{5}$ Didin Hafhiduddin, Dakwah Aktual, cet. I (Jakarta: Gema Insani, 1998), 120.

${ }^{6}$ Nanih Mahendrawati dan Agus Ahmad Syafe'i, Pengembangan Masyarakat Islam, cet. I (Bandung: Rosdakarya, 2001), 66.

${ }^{7}$ Jalaludin Rahmat, Islam Aktual Refleksi Sosial Seseorang Cendekiawan Muslim, cet. II (Bandung: Mizan, 1999), 232-233. 
dan pelatihan entrepreneur yang mengintegrasikan skill (kemampuan), knowledge (pengetahuan), attitude (sikap), cerdas intelektual, cerdas emosional, dan cerdas spiritual. ${ }^{8}$

Lebih dari sekedar interaksi antara kyai dan santri, bahkan pesantren juga berinteraksi dengan masyarakat sekitar. Interaksi tersebut pada akhirnya mengalami transformasi makna dan peran, yakni mengarahkan kepada perubahan, pengembangan dan keberdayaan santri, yang diwujudkan dalam bentuk yang beraneka ragam, termasuk ke dalam kepedulian terhadap masalah yang dihadapi khususnya masalah ekonomi.

Terkait dengan masalah ekonomi, pondok pesantren dengan eksistensinya sebagai salah satu lembaga yang mempunyai pengaruh kuat untuk memberdayakan masyarakat melalui program-program yang ditawarkan oleh pondok pesantren baik yang berkenaan dengan pendidikan keagamaan sampai kepada pelatihan kewirausahaan, hal ini yang memotivasi beberapa pondok pesantren untuk mencoba memadukan sistem pendidikan agama dengan pendidikan kewirausahaan.

Salah satu pondok pesantren yang memiliki peran besar untuk mencetak wirausaha Muslim ialah Pondok Pesantren Wirausaha Lantabur Kota Cirebon. Selain santri di didik untuk menadalami ilmu agama, pondok pesantren Lantabur juga memberikan pelatihan kewirausahaan kepada para santrinya melalui unit usaha pondok. Disinilah potensi pondok pesantren, yakni dengan melakukan perannya sebagai lembaga kemasyarakatan untuk meningkatkan inisiatif dan kreatif dari masyarakat sebagai sumber utama pembangunan dan yang menekankan kesejahteraan material dan spiritual

${ }^{8}$ Tentang peran pesantren yang demikian, lihat Taufik Abdullah, Islam dan Masyarakat (Jakarta: LP3Es, 1996), iii. masyarakat sebagai tujuan dari proses pembangunan.

Sedangkan dalam ilmu ekonomi, seorang pengusaha berarti seorang pemimpin ekonomi yang mempunyai kemampuan untuk mendapatkan peluang secara berhasil memperkenalkan mata dagangan baru, teknik baru, sumber pemasukan baru, dan merangkum pabrik, peralatan, manajemen, dan tenaga buruh yang diperlukan serta mengorganisasikannya ke dalam suatu teknik pengoperasian perusahaan. Dalam pengertian manapun, pengusaha adalah tokoh dari setiap usaha bisnis, karena tanpa dia roda perindustrian di dalam perekonomian tidak dapat bergerak.

Berkenaan dengan hal tersebut, Pondok Pesantren Wirausaha Lantabur Kota Cirebon yang merupakan salah satu pesantren di Jawa Barat, mempunyai komitmen besar dalam pengembangan kewirausahaan bagi santrinya dan warga sekitarnya. Kehidupan para santri inilah yang menjadikan objek penelitian penulis. Di samping itu, dari adanya unit usaha binis Pondok Pesantren Wirausaha Lantabur ini, penulis ingin menggali potensi yang dimiliki oleh Pondok Pesantren Wirausaha Lantabur, karena bukan hanya santri yang diberdayakan, terdapat pula sejumlah masyarakat yang diberdayakan melalui unit usaha mitra pondok pesantren. Oleh karena itu, santri bukan hanya diajarkan semangat dakwah Islam tetapi juga dibekali dengan semangat berwirausaha. Sesuai dengan visi Pesantren Wirausaha Lantabur yang dikutip dari lantabur press, yaitu "menjadikan pesantren wirausaha Islam terkemuka, yang mampu mengantarkan wirausahawan muslim yang profesional dan mandiri”.

Berdasarkan uraian di atas, untuk mengetahui lebih lanjut dan berpijak pada latar belakang di atas, penulis merumuskan beberapa masalah yaitu pertama, bagaimana strategi pemberdayaan ekonomi santri dan masyarakat di lingkungan Pondok Pesantren Wirausaha Lantabur Kota Cirebon? Kedua, bagaimana dampak strategi pemberdayaan 
ekonomi terhadap santri dan masyarakat di lingkungan Pondok Pesantren Wirausaha Lantabur Kota Cirebon?

Dan ketiga, apa saja faktor pendukung dan penghambat dalam proses pemberdayaan ekonomi santri dan masyarakat di lingkungan Pondok Pesantren Wirausaha Lantabur Kota Cirebon?

\section{KONSEP DASAR}

Dalam buku management strategi (strategy). Strategi diartikan oleh manajer sebagai rencana skala besar yang berorientasi jangka panjang untuk berinteraksi dengan lingkungan yang kompetitif untuk mencapai tujuan perusahaan. ${ }^{9}$ Strategi adalah langkahlangkah yang harus dijalankan oleh suatu perusahaan untuk mencapai tujuan. Kadangkadang langkah yang harus dihadapi terjal dan berliku-liku, namun ada juga langkah yang relatif mudah.

Di samping itu, banyak rintangan atau cobaan yang dihadapi untuk mencapai tujuan. Oleh karena itu, setiap langkah harus dijalankan secara hati-hati dan terarah. ${ }^{10}$ Jadi, dapat disimpulkan bahwa strategi pemberdayaan ekonomi adalah proses menemukan potensi yang terdapat pada sebuah kelompok masyarakat atau organisasi untuk memaksimalkan potensi yang ada melalui keinginan kuat untuk menjadi mandiri dan lebih baik.

Sedangkan, konsep pemberdayaan dalam wacana pembangunan biasanya selalu dikaitkan dengan konsep kemandirian, partisipasi, jaringan kerja, dan keadilan. Menurut Craig dan Mayo dalam penelitian Nugroho, partisipasi merupakan komponen terpenting dalam upaya pertumbuhan kemandirian dan proses pemberdayaan. Strategi pemberdayaan menempatkan partisipasi masyarakat sebagai isu pertama

${ }^{9}$ John A. Pearce I. dan Richard B. Robinson, Jr., Manajemen Strategis-Formulasi, Implementasi, dan Pengendalian, terj. Nia Pramita Sari (Jakarta: Salemba Empat, 2013), 4.

${ }^{10}$ Kasmir, Kewirausahaan (Jakarta: PT. RajaGrafindo Persada, 2010), 171. pembangunan saat ini. ${ }^{11}$ Dalam hal ini, masih banyak pengertian pemberdayaan menurut para ahli seperti menurut Zubaedi dalam bukunya menjelaskan bahwa pemberdayaan masyarakat adalah upaya untuk meningkatkan harkat dan martabat golongan masyarakat yang sedang kondisi miskin, sehingga mereka dapat melepaskan diri dari perangkap kemiskinan dan keterbelakangan.

Pemberdayaan adalah upaya untuk membangun kemampuan masyarakat dengan mendorong, memotivasi, dan membangkitkan kesadaran akan potensi yang demikian dan berupaya untuk mengembangkan potensi ini menjadi tindakan daya. ${ }^{12}$

Menurut Sumodiningrat, berpendapat bahwa pemberdayaan masyarakat harus dilakukan melalui 3 (tiga) jalur, yaitu pertama, menciptakan iklim yang memungkinkan potensi masyarakat berkembang (Enabling). Kedua, menguatkan potensi dan daya yang dimiliki masyarakat (Empowering). Dan ketiga, memberikan perlindungan (Protecting).

Pemberdayaan masyarakat merupakan suatu upaya untuk meningkatkan kemampuan masyarakat agar mampu mewujudkan kemandirian dan melepaskan diri dari belenggu kemiskinan serta keterbelakangan. ${ }^{13}$

Selanjutnya, pemberdayaan di bidang ekonomi merupakan upaya untuk membangun daya (masyarakat) dengan mendorong, memotivasi, dan membangkitkan kesadaran akan potensi ekonomi yang dimilikinya serta berupaya untuk mengembangkannya. Keberdayaan masyarakat adalah unsur dasar yang

${ }^{11}$ Trilaksono Nugroho, Paradigma, Model, Pendekatan Pembangunan, dan Pemberdayaan Masyarakat di Era Otonomi Daerah (Malang: FIA Universitas Brawijaya, 2007), 21.

${ }^{12}$ Zubaedi, Wacana Pengembangan Alternatif (Yogyakarta: Ar-Ruzz Media, 2007), 41-42.

${ }^{13}$ Gunawan Sumodiningrat, Pemberdayaan Masyarakat dan Jaring Pengamanan Sosial (Yogyakarta: Ghalia Indonesia, 1999), 133-134. 
memungkinkan suatu masyarakat bertahan. Dalam pengertian yang dinamis, yaitu mengembangkan diri dan mencapai kemajuan. Keberdayaan masyarakat menjadi sumber dari apa yang dikenal sebagai Ketahanan Nasional. ${ }^{14}$

Sejak berdiri pada abad ke-14 Masehi, pesantren memiliki fungsi sebagai lembaga dakwah, lembaga pendidikan dan pengkaderan ulama serta pusat perjuangan ummat dalam melawan penjajah, maka pada tahun 1980-an, melalui Pusat Pengembangan Pesantren dan Masyarakat $(\mathrm{P} 3 \mathrm{M})^{15}$, dunia pesantren memperoleh tambahan fungsi baru, yaitu sebagai pusat pemberdayaan masyarakat. Maka banyak pesantren yang dijadikan sebagai uji coba untuk program pemberdayaan masyarakat. Kita kenal beberapa pesantren, misal Pesantren Darul Falah Bogor, Pesantren Pabelan Magelang, Pesantren Kajen Pati, Pesantren Langitan Tuban, Pesantren AnNuqayah Madura dan sebagainya yang dijadikan sebagai pusat pemberdayaan masyarakat. Hiruk pikuk pemberdayaan masyarakat kemudian menjadi luar biasa di dunia pesantren.

Kemudian di era 2000-an, pesantren memperoleh tambahan fungsi baru lagi yaitu sebagai pusat pengembangan ekonomi kerakyatan. Maka muncullah pesantren dengan ciri khasnya mengembangkan koperasi, seperti Pesantren Sidogiri. Hal ini menandai bahwa dunia pesantren sesungguhnya tidak sepi dari inovasi yang

\footnotetext{
${ }^{14}$ Mubyarto, Membangun Sistem Ekonomi (Yogyakarta: BPFE, 2000), 263-264.

${ }^{15}$ Pusat Pengembangan Pesantren dan Masyarakat (P3M) adalah sebuah lembaga atau organisasi sosial kemasyarakatan dan nonpemerintah (NGO) yang berbasis pada komunitas pesantren sebagai pusat pendidikan dan keagamaan masyarakat. P3M didirikan oleh sejumlah kyai pengasuh pondok pesantren dan beberapa tokoh masyarakat sipil nasional untuk mewadahi dan memfasilitasi kepentingan pesantren dalam penguatan dirinya melalui perkhidmatan kepada masyarakat sekitar dan lingkungannya. Lembaga atau organisasi ini menjalankan kegiatannya di Jakarta, sejak berdirinya tahun 1983 .
}

terus menerus dilakukan. Dan hal ini juga menandakan bahwa dunia pesantren memiliki respon yang sangat tinggi terhadap perubahan zaman. Jadi, sesungguhnya pesantren adalah lembaga sosial dan pendidikan yang dapat menjadi pilar pemberdayaan masyarakat.

Secara garis besar, peran strategis pondok pesantren dalam ekonomi syariah ada dua; Pertama, peran pengembangan keilmuan dan sosialisasi ekonomi syariah ke masyarakat. Hal ini karena pesantren diakui sebagai lembaga pengkaderan ulama dan da'i yang legitimed di masyarakat. Ulama produk pesantren sangat berpotensi menjadi ulama ekonomi Islam yang sangat diperlukan sebagai Dewan Pengawas Syari'ah (DPS) bagi Lembaga Keuangan Syariah (LKS) yang berfungsi mengawasi dan menjaga aktivitas dan program LKS tersebut sesuai dengan syariah. Disamping itu mereka juga dapat berperan sebagai corong sosialiasi ekonomi syariah di masyarakat, karena mereka adalah panutan dan suara mereka lebih didengar dari pada ulama dan da'i produk lembaga non pesantren. Kelebihan lainnya, mereka lebih menguasai fiqih muamalah, sehingga memiliki kemampuan untuk menjelaskan ekonomi syariah kepada masyarakat dengan lebih baik.

Kedua adalah peran mewujudkan laboratorium praktek riil teori ekonomi syariah dalam aktivitas ekonomi. Peran ini juga sangat strategis, mengingat masyarakat melihat pesantren sebagai contoh dan teladan dalam aktivitas sehari-hari. Jika pesantren mengembangkan potensinya dalam ekonomi syariah dan berhasil tentu hal itu akan diikuti masyarakat. InsyaAllah mereka ramai-ramai melakukan migrasi dari sistem ekonomi kapitalis menuju ekonomi yang terbebas dari riba, maysir, gharar, riswah, dhalim, jual beli barang haram dan berbagai bentuk kemaksiatan lainnya. Sebaliknya, jika pesantren pasif dan apatis tentu berpengaruh kepada masyarakat, 
apalagi jika mereka masih berinteraksi dengan ekonomi konvensional. ${ }^{16}$

Pemberdayaan yang dilakukan oleh pesantren terhadap santrinya yaitu pemberdayaan melalui peningkatkan kompetensi ekonomi para santri agar nantinya para santri tersebut setelah berada kembali di lingkungan masyarakatnya dapat menjadi panutan baik dalam bidang ekonomi produktif atau sebagai kader-kader pemberdaya ekonomi, di samping peran utamanya sebagai ustadz/ustadzah yang mempunyai kemampuan dalam bidang ilmu agama Islam.

Usaha pemberdayaan masyarakat tersebut, bukan hanya tugas dan kewajiban pemerintah semata. Akan tetapi juga menjadi tanggung jawab bagi institusiinstitusi atau organisasi lokal (pondok pesantren) yang ada di masyarakat. Hal ini dapat dijelaskan bahwa secara mendasar dan substantif, organisasi lokal memiliki kegiatan internal dan eksternal. Kegiatan internal berupa konsolidasi dan koordinasi ke dalam dengan membangun solidaritas dan komitmen. Sedang kegiatan eksternal berupa usaha-usaha pemberdayaan dan pelayanan kepada masyarakat. ${ }^{17}$

Santri adalah siswa atau murid lakilaki atau perempuan. Menurut Kamus Umum Bahasa Indonesia susunan W.J.S. Poerwadarminta, kata santri berarti; 1) Orang yang mendalami pengajian dalam agama Islam (dengan pergi ke pesantren, dan sebagainya). 2) Orang yang beribadat sungguh-sungguh. Sekarang ini malah umum dipakai sebutan santriwan (putra) dan santriwati (puteri). ${ }^{18}$

Namun demikian, istilah murid atau siswa lebih umum dipergunakan untuk mereka yang belajar di sekolah umum, yakni bukan di madrasah atau pesantren.

\footnotetext{
${ }^{16} \mathrm{http}: / /$ www.syariah.feb.unair.ac.id. Diakses pada 18 Januari 2016.

${ }^{17}$ Ziemek Manfred, Pesantren dalam Perubahan Sosial (Jakarta: P3M, 1986), 211.

${ }^{18}$ Pusat Bahasa Departemen Pendidikan Nasional, Kamus Besar Bahasa Indonesia (Jakarta: Balai Pustaka, 2002), 211.
}

Untuk mengatur kehidupan pondok pesantren, kyai menunjuk salah seorang santri senior untuk mengatur adik-adik kelasnya. Mereka biasanya di sebut Lurah Pondok. Menurut Zamakhsari Dhofier, santri merupakan elemen penting dalam suatu lembaga pesantren. Terdapat 2 (dua) kelompok santri, yaitu 1) Santri mukim, murid-murid yang berasal dari daerah yang jauh dan menetap dalam kelompok pesantren. 2) Santri kalong, murid-murid yang berasal dari desa-desa disekeliling pesantren, dan biasanya tidak menetap di pesantren. Untuk mengikuti pelajaran di pesantren mereka bolak-balik (nglaju) dari tempat tinggalnya. ${ }^{19}$

Dalam makna yang lain masyarakat diartikan sebagai pergaulan hidup manusia (sehimpunan orang yang hidup) bersama disuatu tempat dengan ikatan-ikatan aturan yang tertentu. ${ }^{20}$ Sedangkan jika dikaitkan dengan konteks peranan pesantren, pemberdayaan di sini dimaksudkan sebagai suatu tindakan yang dilakukan oleh pesantren sebagai proses, cara, perbuatan memberdayakan serta membangkitkan kemauan, kemampuan, dan kepercayaan pada diri sendiri, agar mereka dapat terlibat secara aktif dalam suatu gerakan masyarakat yang terlaksana secara metodis, efisien dan terorganisir dalam suatu program yang dilakukan oleh pesantren bersama masyarakat.

Secara umum ada empat strategi pemberdayaan masyarakat, ${ }^{21}$ antara lain;

\section{The Growth Strategy}

Penerapan strategi pertumbuhan pada umumnya yang dimaksudkan ialah untuk mencapai peningkatan yang cepat dalam nilai ekonomis, melalui peningkatan pendapatan perkapita penduduk, produktivitas, pertanian, permodalan, dan

\footnotetext{
${ }^{19}$ www.rayakultural.com. Diakses pada 11 Februari 2017.

${ }^{20}$ W. J. S. Poerwodarminto, Kamus Umum Bahasa Indonesia (Jakarta: Balai Pustaka, 1999), 636.

${ }^{21}$ Tjahya Supriana, Strategi Pembagunan Dan Kemiskinan (Jakarta: Rineka Cipta, 2001), 69-71.
} 
kesempatan kerja dibarengi dengan kemampuan konsumsi masyarakat, terutama dipedesaan.

\section{The Welfare Strategy}

Strategi kesejahteraan ini pada dasarnya dimaksudkan untuk memperbaiki kesejahteraan. Akan tetapi, karena tidak dibarengi dengan pembangunan kultur dan budaya mandiri dalam diri masyarakat yang pada akhirnya yang terjadi adalah sikap ketergantungan masyarakat kepada pemerintah. Jadi, dalam setiap pembangunan masyarakat salah satu aspek yang harus diperhatikan penanganannya adalah kultur dan budaya masyarakat. Pembangunan budaya jangan sampai kontra produktif dan pembangunan ekonomi yaitu dalam konteks yang sesuai dengan model pengembangan masyarakat menjadi sangat relevan sehingga terwujudnya masyarakat mandiri.

\section{The Responsitive Strategy}

Strategi ini merupakan reaksi terhadap strategi kesejahtraan yang dimaksudkan untuk menanggapi kebutuhan yang dirumuskan masyarakat sendiri dengan bantuan pihak luar (self need and assistance) untuk memperlancar usaha mandiri melalui pengadaan teknologi serta sumber yang sesuai bagi kebutuhan proses pembangunan.

\section{The Integrated Holistic Strategy}

Untuk mengatasi dilema pengembangan masyarakat karena "kegagalan" ketiga strategi yang dijelaskan diatas, maka konsep kombinasi dan unsur-unsur pokok dari etika strategi di atas menjadi alternatif terbaik karena secara sistematis mengintegrasikan seluruh komponen dan unsur yang diperlukan yakni, ingin mencapai secara timultan tujuan-tujuan yang menyangkut kelangsungan pertumbuhan, persamaan, kesejahteraan dan partisipasi aktif masyarakat dalam proses pembanguna masyarakat.

\section{METODOLOGI}

Kerangka Pemikiran Penelitian

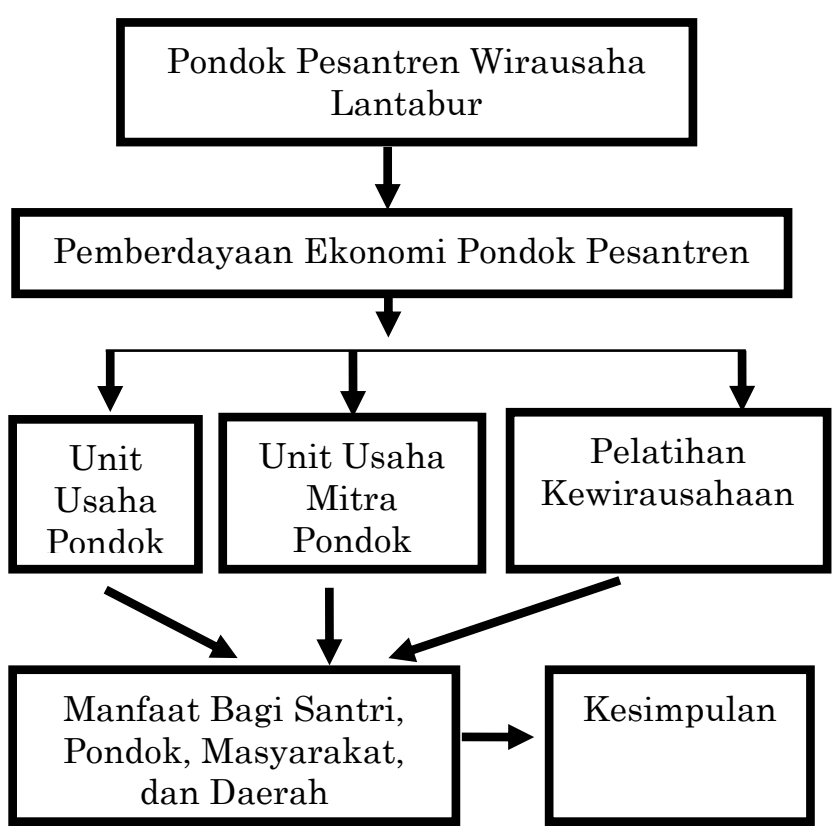

Penelitian ini menggunakan pendekatan penelitian kualitatif, penelitian ini dilakukan di Pondok Pesantren Wirausaha Lantabur Kota Cirebon yang beralamat di Jl. Surapandan RT. 07 / RW. 04 Kelurahan Argasunya Kecamatan Harjamukti Kota Cirebon Jawa Barat pada Mei 2016 Januari 2017. Pada penelitian ini, penulis menggunakan strategi kualitatif yakni studi kasus. Studi kasus merupakan strategi penelitian dimana di dalamnya peneliti menyelidiki secara cermat suatu program, peristiwa, aktivitas, proses, atau sekelompok individu.

Data yang diperlukan adalah data kualitatif. Sumber data yang diperlukan adalah data primer dan data sekunder. Data primer didapatkan dari wawancara dengan informan diantaranya Pelindung Pondok Pesantren, Ketua Pondok Pesantren, Santri, dan beberapa masyarakat yang ada di sekitar pondok pesantren. Data sekunder yang digunakan yaitu buku, skripsi, jurnal, serta data yang berasal dari Pondok Pesantren, dan Kelurahan Argasunya Kota Cirebon. 


\section{Alur Pengolahan Data}

Metode pengumpulan data adalah observasi, wawancara dan dokumentasi, dengan perincian sebagai berikut;

\section{Observasi}

Observasi adalah alat pengumpulan data yang dilakukan dengan cara mengamati dan mencatat secara sistemik gejala-gejala yang diselidiki. ${ }^{22}$ Observasi juga sebagai salah satu cara pengamatan yang dilakukan dengan cara melakukan pengamatan terhadap objek yang akan diteliti. Dalam hal ini peneliti menggunakan observasi non partisipan, yaitu hanya melihat dan mendengarkan pada situasi tertentu tanpa partisipasi aktif didalamnya, ${ }^{23}$ Atau lebih dikenal dengan sebutan observasi partisiatif pasif. $^{24}$

Observasi ini dilakukan untuk memperoleh data dari informasi melalui keadaan yang sebenarnya, yang dalam hal ini peneliti mengamati strategi pemberdayaan ekonomi santri dan masyarakat di lingkungan Pondok Pesantren wirausaha Lantabur Kota Cirebon.

\section{Wawancara}

Wawancara adalah proses tanya jawab dalam penelitian yang berlangsung secara lisan dimana dua orang atau lebih bertatap muka, mendengarkan secara langsung informasi-informasi atau keterangan-keterangan lebih lanjut. ${ }^{25}$

Melalui wawancara ini, peneliti bermaksud untuk mengetahui sejarah, prosedur, dan strategi pemberdayaan ekonomi santri dan masyarakat di lingkungan Pondok Pesantren wirausaha Lantabur Kota Cirebon.

${ }^{22}$ Cholid Narbuko dan Abu Ahmadi, Metodologi Penelitian (Jakarta: Bumi Aksara, 2007), 70.

${ }^{23}$ Emzir, Metodologi Penelitian Kualitatif: Analisis Data (Jakarta: Rajawali Press, 2012), 40.

${ }^{24}$ Sugiono, Memahami Penelitian Kualitatif (Bandung: Alfabeta, 2014), 62.

${ }^{25}$ Cholid Narbuko dan Abu Ahmadi, Metodologi Penelitian, 83.

\section{Dokumentasi}

Perlengkapan dokumentasi yang digunakan untuk kegiatan wawancara ini, seperti daftar pertanyaan, buku catatan, alat untuk mendokumentasikan, recorder, dan sebagainya.

\section{Teknik Analisis}

Dalam penelitian ini digunakan teknik analisis data induktif (inductive data analysis), yakni para peneliti kualitatif membangun pola-pola, kategori-kategori, dan tema-temanya dari bawah ke atas (induktif), dengan mengolah data ke dalam unit-unit informasi yang lebih abstrak. Proses induktif ini mengilustrasikan usaha peneliti dalam mengolah secara berulangulang tema-tema dan database penelitian hingga peneliti berhasil membangun serangkaian tema yang utuh.

Pada penelitian ini, menggunakan teknik keabsahan data yakni mentriangulasi (triangulate) sumber-sumber data yang berbeda dengan memeriksa bukti-bukti yang berasal dari sumber-sumber tersebut dan menggunakannya untuk membangun justifikasi tema-tema secara koheren, menerapkan member cheking untuk mengetahui akurasi hasil penelitian.

Member cheking ini dapat dilakukan dengan membawa kembali hasil laporan akhir atau deskripsi-deskripsi atau tematema spesifik ke hadapan partisipan untuk mengecek apakah mereka merasa bahwa laporan/ deskripsi/tema tersebut sudah akurat, membuat deskripsi yang kaya dan padat (rich and thick description) tentang hasil penelitian.

Deskripsi ini setidaknya harus berhasil menggambarkan setting penelitian dan membahas salah satu elemen dari pengalaman-pengalaman partisipan, memanfaatkan waktu yang relatif lama (prolonged time) dilapangan atau lokasi penelitian, melakukan tanya-jawab dengan sesama rekan peneliti (peer debriefing) untuk meningkatkan keakuratan hasil penelitian. Proses ini mengharuskan peneliti mencari seorang rekan (a peer debriefer) 
yang dapat me-review untuk berdiskusi mengenai penelitian kualitatif sehingga hasil penelitiannya dapat dirasakan oleh orang lain, selain oleh peneliti sendiri.

\section{HASIL DAN PEMBAHASAN}

Terdapat beberapa strategi mengenai pemberdayaan ekonomi yang dilakukan oleh pondok pesantren wirausaha lantabur untuk membina jiwa entrepreneur santri, dan masyarakat sekitar antara lain sebagai berikut:

\section{Pemberdayaan Ekonomi Santri}

Dalam upaya mencetak wirausahawan Muslim yang kompeten, pondok pesantren fokus terhadap pengembangan unit usaha pesantren yang meliputi peternakan kambing, budidaya ikan lele, dan lahan perkebunan. Semua unit usaha bisnis tersebut dipilih sesuai dengan potensi dan letak geografis pondok pesantren. Santri bukan hanya diberikan pendidikan wirausaha melalui unit usaha pondok pesantren, akan tetapi apabila santri telah menyelesaikan pendidikannya di pesantren dapat diberikan izin untuk menjalani proses magang pada unit usaha mitra pondok.

\section{Pemberdayaan Ekonomi Masyarakat}

Menurut Isbandi Rukminto Adi yang dikutip oleh Deden Fajar Badruzzaman, salah satu upaya untuk memberdayakan masyarakat dapat dilakukan dengan cara menumbuhkan keinginan masyarakat untuk berwiraswasta, bergelut dalam aspek ekonomi, bertindak dengan merancang munculnya diskusi tentang apa yang menjadi masalah dalam masyarakat dan memberikan informasi tentang pengalaman kelompok lain yang telah sukses dan sejahtera. ${ }^{26}$ Oleh karena itu, adanya unit usaha mitra pondok pesantren yang tidak lain sebagai tempat magang para santri setelah menyelesaikan pendidikan

\footnotetext{
${ }^{26}$ Deden Fajar Badruzzaman, Pemberdayaan Kewirausahaan Terhadap Santri (Studi Kasus : Pondok Pesantren Al-Ashriyyah Nurul Imam Parung, Bogor), Skripsi (Jakarta: UIN Syarif Hidayatullah, 2009), 17.
}

selama di pesantren, secara tidak langsung dapat memberikan lapangan pekerjaan bagi masyarakat di sekitar pondok pesantren.

Saat ini, ada beberapa unit usaha pribadi milik Dede Muharam yang siap untuk dijadikan tempat magang bagi para alumni Pondok Pesantren Wirausaha Lantabur dan sekaligus membantu perekonomian masyarakat sekitar, diantaranya 1) Salam Tour, 2) Bengkel Las Madani, 3) Laundry Madani, 4) Depo Keramik, dan 5) Andalus City.

\section{Pemberdayaan Ekonomi Melalui Pelatihan Kewirausahaan}

Pondok Pesantren Wirausaha Lantabur berusaha mengadakan acara pelatihan kewirausahaan pada tanggal $10 \mathrm{~s} / \mathrm{d} 16$ Oktober 2016 atau 9 s/d 15 Muharrom H. Pelatihan kewirausahaan ini bertempat di Pondok Pesantren Wirausaha Lantabur Cirebon. Pada intinya, kegiatan ini bertujuan untuk membangkitkan jiwa entrepreneur pada generasi muda, yang saat ini tengah diupayakan untuk menambah wirausahawan baru di dunia perekonomian, sehingga nantinya diharapkan dapat membuka lowongan pekerjaan baru dan secara tidak langusng dapat mengurangi angka pengangguran di Indonesia.

Dampak positif dari strategi pemberdayaan ekonomi yang dilakukan oleh Pondok Pesantren terhadap santri dan masyarakat di sekitar Pondok Pesantren Wirausaha Lantabur secara langsung dapat memberikan skill kewirausahaan bagi kemandirian santri melalui unit usaha pondok dan secara tidak langsung dapat menyerap tenaga kerja.

Faktor Pendukung dan Penghambat dalam P roses Pemberdayaan Ekonomi

Faktor pendukung dan penghambat dalam pemberdayaan ekonomi di lingkungan Pondok Pesantren Wirausaha Lantabur Kota Cirebon. Dari penelitian aktivitas pondok pesantren dan dari beberapa unit bisnis yang telah dikembangkan pondok pesantren, penulis mendapatkan beberapa 
informasi serta hasil observasi, dokumentasi dan wawancara.

Penulis telah menganalisis beberapa faktor pendukung dan penghambat dalam pemberdayaan ekonomi bagi santri dan masyarakat di lingkungan Pondok Pesantren Wirausaha Lantabur Kota Cirebon, yaitu:

\section{Faktor Pendukung}

Ada beberapa faktor pendukung dalam strategi pemberdayaan ekonomi santri dan masyarakat di lingkungan Pondok Pesantren Wirausaha Lantabur Kota Cirebon, yaitu;

Pertama, adanya peralatan yang sudah cukup mendukung. Terdapat peralatan yang sudah disediakan oleh pengurus pondok pesantren untuk memulai usaha. Seperti dalam pembuatan kolam ikan lele yang menggunakan terpal, pihak pondok pesantren telah menyiapkan beberapa terpal yang berukuran 4 × 6 meter, dalam bidang peternakan pihak pengurus pondok juga telah menyiapkan beberapa peralatan seperti: gergaji, untuk memotong kayu guna memperbaiki kandang kambing yang rusak. Kayu, untuk mengganti kayu yang sudah rusak yang terdapat dikandang kambing sudah dimakan rayap. Sekop, untuk mengambil kotoran kambing yang sudah menumpuk.

Dalam bidang pertanian, pihak Pondok Pesantren Wirausaha antabur telah menyiapkan lahan pertanian seluas 2 ha untuk dijadikan media tanam, pihak pondok pesantren juga telah menyiapkan beberapa cangkul untuk menggarap lahan, dan menyiapkan bibit tanaman.

Kedua, adanya pengawasan dari pengurus pondok. Adanya pengawasan dari pihak pengurus pondok ini dapat mengontrol santri dalam berwirausaha, serta melakukan penilian terhadap unit bisnis yang tengah dikembangkan di Pondok Pesantren.

Dan ketiga, adanya Networking yang cukup bagus dari Jama'ah Salam Tour Pondok. Pesantren Wirausaha Lantabur memiliki jaringan yang kuat untuk pengembangan pondok pesantren. Hal ini dapat dilakukannya kerja sama dalam bidang bisnis.

\section{Faktor Penghambat}

Adapun terkait faktor penghabatnya, dapat dinyatakan beberapa hal berikut;

Pertama, terbatasnya Jumlah Santri. Pondok pesantren Wirausaha Lantabur masih memerlukan santri baru untuk menunjang perkembangan unit bisnis yang telah dikelola dan dapat memberdayakan santri secara menyeluruh.

Kedua, minimnya Tenaga Pengajar. Masih terbatasnya jumlah pengajar di pondok pesantren ini. Hal ini sangat dibutuhkan untuk memberikan semangat kelimuan bagi pondok pesantren terutama dalam pengembangan unit bisnis pesantren.

Ketiga, perbedaan Metode Pembelajaran. Jika pondok pesantren saat ini didominasi oleh pondok pesantren tahfiz yang sebagian besar hanya fokus terhadap penghafalan Al-Qur'an akan tetapi berbeda halnya dengan Pondok Pesantren Wirausaha Lantabur. Di Pondok Pesantren ini, selain diajarkan ilmu agama santri di ajarkan untuk berhidmat kepada pondok, membantu keperluan Pondok dan ikut serta membangun perekonomian dengan cara berwirausaha. Hal ini yang agak sedikit berbeda dengan metode pembelajaran yang ada di Pondok Pesantren pada umumnya.

Dan keempat, lemahnya Semangat Wirausaha di Kalangan Masyarakat. Tentu saja, dalam bisnis orang dituntut berani bertaruh, mengambil risiko, berani mengambil langkah-langkah strategis tertentu agar berhasil dalam bisnisnya. Sebab yang dipertaruhkan dalam bisnis tidak saja bagaimana mendapatkan uang dan barang material, tetapi dipertaruhkan pula harga diri pebisnis tersebut, menjaga nama baik, keluarga, hidup karyawannya dan masyarakat memiliki hak akan kehidupan sosial yang baik dan atas lingkungan yang sehat. $^{27}$

\footnotetext{
${ }^{27}$ Observasi pada 15 Februari 2017.
} 


\section{KESIMPULAN}

Berdasarkan uraian di atas, dapat ditarik 3 (tiga) kesimpulan yaitu pertama, strategi pemberdayaan santri dan masyarakat yang dilakukan oleh Pondok Pesantren Wirausaha Lantabur Kota Cirebon ialah pemberdayaan melalui unit usaha pondok pesantren yang terdiri dari; Peternakan kambing, Budidaya ikan lele, dan Perkebunan. Santri juga diberikan kesempatan untuk menjalani magang di beberapa unit usaha mitra pondok yang didirikan oleh Bapak H. Dede Muharam, Lc. Pemberdayaan masyarakat melalui unit usaha mitra pondok yang terdiri dari; Salam Tour, Laundry Madani, Bengkel Madani, Andalus City, dan Depo Keramik Andalus.

Kemudian untuk mensosialisasikan program-program pondok pesantren, pihak pondok juga berusaha melakukan pemberdayaan ekonomi melalui pelatihan kewirausahaan, pada pelatihan ini melibatkan masyarakat umum dan sejumlah mahasiswa.

Kedua, dampak dari adanya unit usaha pondok bagi santri, ialah mereka dapat belajar mencari nafkah, memiliki skill kewirausahaan sehingga suatu saat diharapkan alumni pondok dapat membuka unit usaha baru agar dapat membantu dalam mengurangi angka pengangguran. Sedangkan dampak positif yang dirasakan oleh masyarakat di lingkungan Pondok Pesantren Wirausaha Lantabur Kota Cirebon ialah mendapat ilmu dari unit bisnis yang mereka bekerja di dalamnya. Diharapkan masyarakat yang dipekerjakan pada unit usaha mitra pondok ini mendapatkan ide atau gagasan untuk membuka unit usaha sendiri, sehingga mampu membuka lapangan pekerjaan bagi yang membutuhkan.

Dan ketiga, program-program pemberdayaan telah berhasil dilakukan oleh pihak Pondok Pesantren Wirausaha Lantabur Kota Cirebon, akan tetapi dalam pelaksanaanya masih terdapat faktor pendukung dan penghambat. Faktor pendukung antara lain; adanya peralatan yang sudah cukup mendukung. Adanya pengawasan dari pengurus pondok, dan adanya networking yang cukup bagus dari Jama'ah Salam Tour.

Faktor penghambat antara lain; terbatasnya jumlah santri, kurangnya tenaga pengajar, perbedaan metode pembelajaran, dan masih lemahnya semangat berwirausaha di kalangan masyarakat.

\section{DAFTAR PUSTAKA}

Abdullah, Taufik. Islam dan Masyarakat. Jakarta: LP3Es, 1996.

Badruzzaman, Deden Fajar. Pemberdayaan Kewirausahaan Terhadap Santri. Studi Kasus : Pondok Pesantren AlAshriyyah Nurul Imam Parung, Bogor), Skripsi. Jakarta: UIN Syarif Hidayatullah, 2009.

Emzir. Metodologi Penelitian Kualitatif: Analisis Data. Jakarta: Rajawali Press, 2012.

Faozan, Ahmad. "Pondok Pesantren dan Pemberdayaan Ekonomi", Jurnal Ibda', Vol. 4, No. 1 (Juni, 2006).

Hafhiduddin, Didin. Dakwah Aktual, cet. I. Jakarta: Gema Insani, 1998.

http://www.syariah.feb.unair.ac.id.

Indra, Hasbi. Pesantren dan Transformasi Sosial Study atas Pemikiran KH. Abdullah Syafe'i dalam Bidang Pendidikan Islam. Jakarta: Permadani, 2005.

Kasmir, Kewirausahaan. Jakarta: PT. RajaGrafindo Persada, 2010.

Mahendrawati, Nanih dan Agus Ahmad Syafe'i, Pengembangan Masyarakat Islam, cet. I. Bandung: Rosdakarya, 2001.

Manfred, Ziemek. Pesantren dalam Perubahan Sosial. Jakarta: P3M, 1986.

Mubyarto. Membangun Sistem Ekonomi. Yogyakarta: BPFE, 2000.

Narbuko, Cholid dan Abu Ahmadi. Metodologi Penelitian (Jakarta: Bumi Aksara, 2007. 
Nugroho, Trilaksono. Paradigma, Model,

Pendekatan Pembangunan, dan

Pemberdayaan Masyarakat di Era

Otonomi Daerah. Malang: FIA

Universitas Brawijaya, 2007.

Pearce I., John A. dan Richard B.

Robinson, Jr. Manajemen Strategis-

Formulasi, Implementasi, dan

Pengendalian, terj. Nia Pramita Sari.

Jakarta: Salemba Empat, 2013.

Poerwodarminto, W. J. S. Kamus Umum

Bahasa Indonesia. Jakarta: Balai Pustaka, 1999.

Pusat Bahasa Departemen Pendidikan

Nasional, Kamus Besar Bahasa

Indonesia. Jakarta: Balai Pustaka, 2002.

Rahmat, Jalaludin. Islam Aktual Refleksi

Sosial Seseorang Cendekiawan

Muslim, cet. II. Bandung: Mizan, 1999.

Suaiybah, Ebah. "Pemberdayaan Ekonomi

Santri Melalui Penanaman Jamur

Tiram (Studi Kasus di Pondok

Pesantren Al-Ma'muroh Desa

Susukan Kecamatan Cipicung

Kabupaten Kuningan Jawa Barat)".

Skripsi. Yogyakarta: UIN Sunan

Kalijaga, 2009.

Sugiono. Memahami Penelitian Kualitatif. Bandung: Alfabeta, 2014.

Suhartini. "Problem Kelembagaan Pengembangan Ekonomi Pesantren", dalam Pustaka Pesantren (ed.), Manajemen Pesantren. Yogyakarta: LKIS, 2009.

Sumodiningrat, Gunawan. Pemberdayaan Masyarakat dan Jaring Pengamanan Sosial. Yogyakarta: Ghalia Indonesia, 1999.

Supriana, Tjahya. Strategi Pembagunan

Dan Kemiskinan. Jakarta: Rineka

Cipta, 2001.

www.rayakultural.com.

Zubaedi, Wacana Pengembangan Alternatif.

Yogyakarta: Ar-Ruzz Media, 2007. 